\title{
Influence of the abstinence period on human sperm quality: analysis of 2,458 semen samples
}

\author{
Vanessa A. Comar ${ }^{1}$, Claudia G. Petersen ${ }^{1,2}$, Ana L. Mauri ${ }^{1,2}$, Mariana Mattila ${ }^{1}$, Laura D. Vagnini ${ }^{2}$, Adriana Renzi ${ }^{2}$, \\ Bruna Petersen ${ }^{2}$, Andreia Nicoletti ${ }^{1}$, Felipe Dieamant ${ }^{1,2}$, João Batista A. Oliveira ${ }^{1,2}$, Ricardo L. R. Baruffi ${ }^{1,2}$, José \\ G. Franco Jr. ${ }^{1,2}$
}

${ }^{1}$ Center for Human Reproduction Prof. Franco Jr., Ribeirão Preto, SP, Brazil

2Paulista Center for Diagnosis Research and Training, Ribeirão Preto, SP, Brazil

\begin{abstract}
Objective: The aim of this study was to evaluate the influence of different periods of abstinence on conventional semen parameters as well as functional parameters in human semen, including mitochondrial function, chromatin packing and sperm DNA fragmentation.

Methods: We recruited a cohort of 2,458 men undergoing infertility investigation. Semen analyses were performed according to WHO guidelines/morphologymotile sperm organelle morphology examination/MSOME. For DNA integrity analysis, the percentages of DNA fragmentation (TUNEL), abnormal chromatin packaging/ underprotamination (chromomycin $\mathrm{A} 3 / \mathrm{CMA}_{3}$ ), abnormal mitochondrial membrane potential (MMP/MitoTracker Green), and apoptosis (annexin-V) were recorded. Associations between the sexual abstinence period and sperm parameters were assessed using Spearman correlation. For group comparisons, the subjects were categorized according to the sexual abstinence period (SAP) into three groups: SAP $<2$ days, SAP 2-5 days, and SAP $>5$ days.

Results: The duration of abstinence had a statistically significant positive influence on sperm concentration and volume, the number of leukocytes and a statistically significant negative influence on sperm motility and vitality. The percentages of DNA fragmentation and MMP (mitochondrial damage) worsened with the increased duration of abstinence. The percentage of sperm protamination was statistically significantly increased with abstinence.

Conclusion: Increase in the sexual abstinence period influences sperm quality. This study reinforces the importance of the duration of ejaculatory abstinence on semen parameter variation. It highlights the deleterious effect of increased abstinence on DNA damage, which is most likely associated with ROS (mitochondrial damage/ number of leukocytes). The increase in chromatin packaging can represent a protective feature for DNA.
\end{abstract}

Keywords: abstinence period, sperm parameters, DNA fragmentation, concentration, motility, volume.

\section{INTRODUCTION}

Semen analysis implies the evaluation of several characteristics of the ejaculate with the intent of estimating the reproductive chance/probability of an individual. Studies have found that human semen samples vary over time and this may be due to three principal factors: (i) pre-analytical influences (in the case of semen: sexual abstinence period and transport of the sample to the laboratory); (ii) analytical randomization (precision) and systematic error (bias); and (iii) inherent biological variation (WHO, 2010;
Castilla et al., 2006; Alvarez et al., 2003; Cardona Maya et al., 2007). The search for predictors of male fertility has resulted in the standardization of procedures for the evaluation of human semen; an example of this is the set of guidelines developed by the $\mathrm{WHO}$, to process seminal samples based on global demographic population studies (WHO, 2010). This effort has made a solid contribution to semen analysis and has provided a better understanding of human sperm quality (Mayorga-Torres et al., 2015).

Human sperm is produced in the seminiferous tubules, and then stored in the epididymis for future release (Sullivan et al., 2016; Mayorga-Torres et al., 2015). Unlike other species, for the male mammalian gamete to mature and acquire fertilization potential it must pass through the epididymis, where it undergoes a series of physiological and biochemical changes (Sullivan et al., 2016). Epididymal transit time was estimated between 2 to 11 days (Mayorga-Torres et al., 2015). The variation is influenced by ejaculatory frequency (Mayorga-Torres et al., 2015). The World Health Organization (WHO) recommends a period of abstinence 2-7 days prior to collection for standard semen evaluation (WHO, 2010). However, recent studies have suggested that shorter abstinence is better for assisted reproductive techniques (ART) than the abstinence recommended by the WHO for performing seminal diagnostic analysis. The abstinence period is important to ensure both the quantity and the quality of spermatozoa, required for successful, natural and assisted conception (Lehavi et al., 2014).

Long-term abstinence leads to the buildup of spermatozoa in the epididymis, and it may increase their exposure to the harmful effects of reactive oxygen and nitrogen species (ROS and RNS) generated mainly by granulocytes during maturation and storage in the epididymis. Thus, spermatozoa are susceptible to oxidative attack, and this has been correlated with decreased sperm motility, lipid peroxidation, DNA damage and compromised fertilization rates (Agarwal \& Said, 2003; Du Plessis et al., 2010). Standard semen analysis does not identify sperm senescence or functional impairment. Examining the effect of abstinence at the functional level requires more sensitive sperm tests such as DNA fragmentation (Amann et al., 2009). However, there is a lack of consensus on the exact influence of the abstinence period on both conventional and functional parameters. Thus, the impact of sexual abstinence on conventional sperm parameters is still debatable (Levitas et al., 2005; Gosálvez et al., 2011; Sánchez-Martín et al., 2013; Agarwal et al., 2016; Mayorga-Torres et al., 2015; 2016).

Based on the above evidence, the objective of this study was to evaluate the influence of different periods of abstinence on conventional seminal parameters, as well as functional parameters in human semen, including mitochondrial function, chromatin packing and sperm DNA fragmentation. 


\section{MATERIALS AND METHODS}

\section{Population}

We recruited a cohort of 2,458 men undergoing infertility investigation. In the first evaluation, each man was asked to deliver a semen sample, and the abstinence period was recorded. No instruction about the abstinence period was given before semen collection for the study. Exclusion criteria were azospermia, any known reproductive tract pathology in the last six months, any hormonal therapy in the past six months and chronic medical disorders. Written informed consent was obtained from all participants, and this study was approved by the institutional review board of local ethics committee.

\section{Sample collection}

Semen samples were collected in sterile containers by masturbation. One portion of each semen sample was used for analysis according to the WHO guidelines (WHO, 2010). Another portion of each semen sample was immediately processed for morphological analysis by motile sperm organelle morphology examination (MSOME). The remainder of the semen samples was immediately processed for sperm DNA fragmentation analysis using the TdT (terminal deoxyribonucleotidyl transferase)mediated dUTP nick-end labelling (TUNEL) assay; sperm apoptosis analysis was carried out using the Annexin $\mathrm{V}$ assay, sperm chromatin packing/underprotamination using Chromomycin $\mathrm{A} 3\left(\mathrm{CMA}_{3}\right)$ staining, and sperm mitochondrial membrane potential/mitochondrial damage using MitoTracker Green.

\section{Determination of morphology by MSOME}

MSOME procedures were performed as described previously (Silva et al., 2012; Oliveira et al., 2014). At least 200 motile spermatozoa per sample were evaluated, and the percentages of normal spermatozoa were determined.

\section{Determination of sperm DNA fragmentation}

DNA fragmentation in spermatozoa was measured using the TdT (terminal deoxyribonucleotidyl transferase)mediated dUTP nick-end labelling (TUNEL) assay, which was performed using an in-situ cell death detection kit, with tetramethylrhodamine-labelled dUTP (Roche, Monza, Italy), as described previously (Vagnini et al., 2007; Oliveira et al., 2014). The final evaluation was achieved using a fluorescent (Olympus BX 50) microscope and the percentage of TUNEL-positive spermatozoa was determined. At least 200 sperm were evaluated on each slide, with the appropriate filter.

\section{Determination of sperm chromatin packaging/ underprotamination}

Sperm protamine deficiency (underprotamination/ chromatin) packaging was measured using chromomycin A3 $\left(\mathrm{CMA}_{3}\right)$, as described previously (Franco et al., 2012). The percentage of positive spermatozoa was determined by direct observation in four fields, using a fluorescent microscope (Olympus BX 50) and the percentages of spermatozoa with abnormal chromatin packaging were determined. At least 200 sperm were evaluated on each slide, with the appropriate filter.

\section{Determination of sperm apoptosis}

Sperm apoptosis was measured using annexin- $V$, a calcium-dependent phospholipid-binding protein with a high affinity for phosphatidylserine that is present on the inner leaflet of the sperm membrane, except for apoptotic sperm, in which phosphatidylserine is externalized. The sperm suspensions $\left(1 \times 10^{6} \mathrm{cells} / \mathrm{ml}\right)$ were incubated with $1 \mu \mathrm{L}$ annexin- $\mathrm{V}, 1 \mu \mathrm{L}$ propidium iodide (Dead Cell
Apoptosis Kit with Annexin V Alexa Fluor ${ }^{\circledR} 488$ \& Propidium Iodide (PI); Molecular Probes, Eugene, OR) and $1 \mu \mathrm{L}$ Hoechst 33342 at room temperature for 15 min in a dark environment. PI is a dye impermeable to live cells. After incubation, the suspension was centrifuged at $800 \mathrm{~g}$ for 10 min, and the pellet was mounted on poly-l-lysine-coated slides for examination under a fluorescent microscope (Olympus BX 50). At the analysis, subpopulations of sperm could be identified: annexin V(-)/PI(-) - live intact sperm; annexin $\mathrm{V}(+) / \mathrm{PI}(-)$ - early apoptotic cells; annexin $\mathrm{V}(+/-) /$ $\mathrm{PI}(+)$ - necrotic cells. The percentages of apoptotic cells (defined number of spermatozoa that were stained in green and positive for annexin- $\mathrm{V}$ but excluded the positive for red propidium iodide dye, divided by the total number of spermatozoa) were determined. At least 200 sperm were evaluated on each slide, with the appropriate filter.

Determination of sperm Mitochondrial membrane potential

Sperm mitochondrial membrane potential (MMP), an indicator of sperm functionality, since it expresses sperm mitochondrial function, was determined using MitoTracker Green (Molecular Probes, Eugene, OR, USA). The live sperm suspensions were incubated in PBS containing 20 $\mathrm{nM}$ MitoTracker for $20 \mathrm{~min}$ at $37^{\circ} \mathrm{C}$. To stain the sperm DNA, the samples were subsequently incubated with Hoechst $33342\left(10 \mathrm{~min}, 37^{\circ} \mathrm{C}\right)$. After incubation, the suspension was centrifuged at $800 \mathrm{~g}(10 \mathrm{~min})$, and the pellet was mounted on a microscope slide. The green fluorescence in the midpiece determined the active mitochondria. Sperm samples were examined using a fluorescent microscope (Olympus BX 50) equipped with a triple band pass filter, and the percentages of spermatozoa with altered MMP/ mitochondrial damage (i.e., absence of green fluorescence) were determined. At least 200 sperm were evaluated on each slide, with the appropriate filter.

\section{Quality control}

To control for intra-observer and inter-observer variability, multiple fractions of semen samples were obtained from randomly selected patients. Each sample was studied at least three times by the same examiner (blinded for subject identity). An intra-observer and an inter-observer variation of $\approx 0.5-1 \%$ and $0.5-7 \%$, respectively, were obtained for each parameter analyzed: semen parameters according to the WHO guidelines, normality of the spermatozoon, normality of nuclear form, normality of chromatin, spermatozoa with any nuclear vacuoles, spermatozoa with vacuoles occupying $>50 \%$ of the nuclear area, sperm TUNEL-positive, sperm $\mathrm{CMA}_{3}-$ positive, sperm Annexin V-positive, and sperm MitoTracker Green-positive. These variations are comparable to those of classical sperm quality parameters (Auger et al., 2000).

\section{Sample size}

The sample size was calculated by making a comparison between two proportions. A sample size of 200 sujects in each group has $80 \%$ power to detect an increase of $15 \%$, with a significance level of 0.05 (two-tailed).

\section{Statistical analysis}

The data was analyzed using the StatsDirect statistical software (Cheshire, UK). Potential confounders (age, body mass index (BMI), smoking, alcohol, varicocele and vitamin use) were also noted. Regression and correlation analyses with continuous variables (age, BMI, sperm volume, sperm $\mathrm{pH}$, sperm concentration, percentage of spermatozoa with progressive motility, percentage of total sperm motility, percentages of normal spermatozoa, number of leucocytes and percentage of live spermatozoa (vitality)) were performed using the Spearman rank correlation test. For 
dichotomous variables (smoking, alcohol, varicocele and vitamin use) correlations were performed using logistic regression.

For group comparisons, the following sexual abstinence period (SAP) were used as cut-off points to divide the subjects into three groups: SAP $<2$ days, SAP 2-5 days and SAP $>5$ days. Mann-Whitney $U$ test, Student's t-test and the chi-squared test were used as appropriate. The level of significance was set at $p<0.05$.

\section{RESULTS}

\section{General population characteristics}

The regression analysis did not show a correlation between days of abstinence and men's age, history of fathering at least one child (or generating a pregnancy that had ended in miscarriage), time of infertility, tobacco use, regular alcohol use, presence of varicocele and vitamin supplement use. The comparison between the three SAP Groups confirmed these results. Table 1 summarizes the data.

\section{Semen quality/General semen parameters}

The regression analysis did not show a correlation between sexual abstinence, sperm $\mathrm{pH}$ and morphology $(p>0.05)$. However, significant $(p<0.05)$ decreases in progressive motility, total sperm motility and sperm vitality with increasing periods of sexual abstinence were noticed. On contrary, the duration of abstinence had a statistically significant positive influence on sperm concentration $(p<0.05)$. The group comparison reinforces these outcomes. Table 2 summarizes the data.

Sperm DNA fragmentation/sperm chromatin packing/sperm apoptosis/sperm mitochondrial membrane potential

We found a positively significant correlation between sexual abstinence duration and sperm DNA fragmentation (percentage of sperm TUNEL positive) and percentage of sperm abnormal mitochondrial membrane potential/ mitochondrial damage $(p<0.05)$. However, there was a significant decrease in the percentage of sperm $\mathrm{CMA}_{3}$ positive with increasing sexual abstinence period $(p<0.05)$.
There was no correlation ( $p>0.05)$ between abstinence and sperm apoptosis (percentage of sperm annexin $\mathrm{V}$ positive). The results of the group comparisons confirm the regression analysis results. Table 3 summarizes the results.

\section{DISCUSSION}

The effects of sperm abstinence period on semen quality have been discussed in the literature, but the results are not consistent. We observed in our results that the main changes in different abstinence periods were in semen volume, semen concentration, progressive motility, leukocyte concentration, sperm vitality, DNA fragmentation percentage, $\mathrm{CMA}_{3}$ positivity percentage and abnormal MMP percentage. We did not find a major change in any of the other sperm parameters available, such as semen $\mathrm{pH}$, morphology and apoptosis percentage.

Our results found that an increased abstinence period is associated with decreases in sperm vitality, sperm progressive motility and $\mathrm{CMA}_{3}$ positivity. Several studies have reported similar results, noting an inverse correlation between sperm motility (Rao et al., 2015; Lehavi et al., 2014; Makkar et al., 2001; Hornstein et al., 1992; TurKaspa et al., 1994) and sperm vitality (Mayorga-Torres et al., 2016; Levitas et al., 2005; Agarwal et al., 2016) with semen abstinence period. There is no consensus in the literature, and another author did not observe any correlation between abstinence duration and some of these semen parameters (Mayorga-Torres et al., 2015).

The semen volume, in this study, was significantly increased after longer abstinence (in days). The findings regarding semen volume are compatible with data reported in similarly controlled studies (Rao et al., 2015, Lehavi et al., 2014; Sauer et al., 1988; Blackwell et al., 1992) and with population-based studies (Matilsky et al., 1993; Padova et al., 1998; Le Lannou et al., 1986; Schwartz et al., 1979; Jouannet et al., 1981; Mortimer et al., 1982; De Jonge et al., 2004).

Regarding sperm motility, there was a decrease with longer periods of abstinence. The findings of this study is in accordance with previously published studies (Rao et al., 2015; Lehavi et al., 2014, Makkar et al., 2001; Hornstein

Table 1. Correlation between general population characteristics and Sexual Abstinence Period.

\begin{tabular}{|c|c|c|c|c|c|c|c|c|}
\hline \multirow[b]{2}{*}{ Characteristic } & \multicolumn{3}{|c|}{ Regression analysis } & \multicolumn{5}{|c|}{ Sexual Abstinence Period Groups } \\
\hline & $\mathbf{r} * / O \mathbf{O R} *$ & $\begin{array}{c}95 \% \\
\text { Confidence } \\
\text { Interval }\end{array}$ & $\boldsymbol{p}$ & Total n:2458 & $\begin{array}{c}<2 \text { days } \\
n: 244(10 \%)\end{array}$ & $\begin{array}{c}\text { 2-5 days } \\
n: 1932 \\
(78.6 \%)\end{array}$ & $\begin{array}{c}>5 \text { days } \\
n: 282 \\
(11.4 \%)\end{array}$ & $\boldsymbol{p}$ \\
\hline Age (years) & $r: 0.04$ & -0.002 to 0.08 & 0.06 & $37.7 \pm 6.5$ & $37.6 \pm 6.3$ & $37.6 \pm 6.4$ & $38.3 \pm 7.1$ & 0.21 \\
\hline BMI & $r: 0.01$ & -0.03 to 0.06 & 0.53 & $28.6 \pm 4.4$ & $28.8 \pm 4.3$ & $28.6 \pm 4.4$ & $28.4 \pm 4.4$ & 0.77 \\
\hline $\begin{array}{l}\text { Fathered at least } \\
\text { one child }\end{array}$ & OR: 1.00 & 0.98 to 1.02 & 0.61 & $\begin{array}{c}31.7 \% \\
(779 / 2458)\end{array}$ & $\begin{array}{c}32.4 \% \\
(79 / 244)\end{array}$ & $\begin{array}{c}32.2 \% \\
(622 / 1932)\end{array}$ & $\begin{array}{c}27.7 \% \\
(78 / 282)\end{array}$ & 0.30 \\
\hline $\begin{array}{l}\text { Time of infertility } \\
\text { (years) }\end{array}$ & $r: 0.03$ & -0.01 to 0.07 & 0.13 & $4.0 \pm 3.3$ & $3.8 \pm 2.2$ & $4.0 \pm 2.1$ & $4.2 \pm 3.2$ & 0.21 \\
\hline Tobacco use (\%) & OR: 0.98 & 0.93 to 1.03 & 0.44 & $\begin{array}{c}11.4 \% \\
(281 / 2458) \\
\end{array}$ & $\begin{array}{c}10.2 \% \\
(25 / 244) \\
\end{array}$ & $\begin{array}{c}11.7 \% \\
(226 / 1932) \\
\end{array}$ & $\begin{array}{c}10.6 \% \\
(30 / 282) \\
\end{array}$ & 0.77 \\
\hline $\begin{array}{l}\text { Regular alcohol } \\
\text { use }(\%)\end{array}$ & OR: 0.99 & 0.97 to 1.01 & 0.57 & $\begin{array}{c}66.1 \% \\
(1624 / 2458)\end{array}$ & $\begin{array}{c}64.3 \% \\
(157 / 244)\end{array}$ & $\begin{array}{c}66.6 \% \\
(1287 / 1932)\end{array}$ & $\begin{array}{c}63.8 \% \\
(180 / 282)\end{array}$ & 0.53 \\
\hline Varicocele (\%) & OR: 1.01 & 0.99 to 1.03 & 0.17 & $\begin{array}{c}15.9 \% \\
(391 / 2458)\end{array}$ & $\begin{array}{c}14.9 \% \\
(36 / 244)\end{array}$ & $\begin{array}{c}16.3 \% \\
(315 / 1932) \\
\end{array}$ & $\begin{array}{c}14.2 \% \\
(40 / 282)\end{array}$ & 0.60 \\
\hline $\begin{array}{l}\text { Vitamin supplement } \\
\text { use }(\%)\end{array}$ & OR: 0.98 & 0.95 to 1.03 & 0.56 & $\begin{array}{c}16.2 \% \\
(397 / 2458)\end{array}$ & $\begin{array}{c}17.2 \% \\
(42 / 244)\end{array}$ & $\begin{array}{c}16.2 \% \\
(313 / 1932)\end{array}$ & $\begin{array}{c}14.9 \% \\
(42 / 282)\end{array}$ & 0.77 \\
\hline
\end{tabular}

* Spearman's correlation.

** Logistic regression.

$r$ : Spearman's rank correlation coefficient.

OD: odds ratio.

Values within rows with the same superscript letter were significantly different. 
Table 2. Correlation between general semen parameters and sexual abstinence period.

\begin{tabular}{|c|c|c|c|c|c|c|c|c|}
\hline \multirow[b]{2}{*}{$\begin{array}{l}\text { Semen } \\
\text { Parameters }\end{array}$} & \multicolumn{3}{|c|}{ Regression analysis } & \multicolumn{5}{|c|}{ Sexual Abstinence Period Groups } \\
\hline & $\begin{array}{c}\text { Spearman's } \\
\text { rank } \\
\text { correlation }\end{array}$ & $\begin{array}{c}95 \% \\
\text { Confidence } \\
\text { Interval }\end{array}$ & $\boldsymbol{p}$ & $\begin{array}{c}\text { Total } \\
\text { n:2458 }\end{array}$ & $\begin{array}{l}<2 \text { days } \\
n: 244\end{array}$ & $\begin{array}{l}\text { 2-5 days } \\
n: 1932\end{array}$ & $\begin{array}{c}>5 \text { days } \\
n: 282\end{array}$ & $\boldsymbol{p}$ \\
\hline $\mathrm{pH}$ & r: -0.01 & -0.05 to 0.02 & 0.52 & $8.0 \pm 0.4$ & $8.0 \pm 0.6$ & $8.0 \pm 0.5$ & $8.0 \pm 0.4$ & 0.28 \\
\hline $\begin{array}{l}\text { Volume } \\
(\mathrm{ml})\end{array}$ & $r: 0.10$ & 0.08 to 0.16 & 0.0004 & $2.7 \pm 1.5$ & $2.3 \pm 1.2^{\mathrm{a}, \mathrm{b}}$ & $2.7 \pm 1.6^{a}$ & $2.8 \pm 1.7^{b}$ & $\begin{array}{l}{ }^{\mathrm{a}} 0.0001 \\
\mathrm{~b} 0.0004\end{array}$ \\
\hline $\begin{array}{l}\text { Concentration } \\
\left(\mathrm{m} \mid \times 10^{6}\right)\end{array}$ & $r: 0.12$ & 0.088 to 0.16 & $<0.0001$ & $71.9 \pm 61.1$ & $60.7 \pm 50.0^{\mathrm{a}, \mathrm{b}}$ & $70.4 \pm 61.1^{\mathrm{a}, \mathrm{c}}$ & $92.1 \pm 65.8^{\mathrm{b}, \mathrm{c}}$ & $\begin{array}{c}{ }^{\mathrm{a}} 0.02 \\
\mathrm{~b}, \mathrm{c}<0.0001\end{array}$ \\
\hline $\begin{array}{l}\text { Progressive } \\
\text { motility (rapid + } \\
\text { slow progression) } \\
(\%) \\
\end{array}$ & $r:-0.10$ & -0.10 to -0.02 & 0.0007 & $56.1 \pm 16.7$ & $58.3 \pm 16.2^{\mathrm{a}, \mathrm{b}}$ & $56.1 \pm 16.9^{a, c}$ & $53.8 \pm 16.1^{\mathrm{b}, \mathrm{c}}$ & $\begin{array}{c}{ }^{\mathrm{a}} 0.03 \\
\mathrm{~b} 0.0004 \\
{ }^{\mathrm{c}} 0.01\end{array}$ \\
\hline $\begin{array}{l}\text { Total } \\
\text { motility } \\
(\%)\end{array}$ & $r:-0.10$ & -0.13 to -0.05 & $<0.0001$ & $63.0 \pm 16.2$ & $65.5 \pm 15.6^{a, b}$ & $63.1 \pm 16.2^{\mathrm{a}, \mathrm{c}}$ & $59.7 \pm 16.2^{\mathrm{b}, \mathrm{c}}$ & $\begin{array}{c}\mathrm{a} 0.01 \\
\mathrm{~b}<0.0001 \\
{ }^{\mathrm{c}} 0.0002 \\
\end{array}$ \\
\hline $\begin{array}{l}\text { Normal } \\
\text { sperm } \\
\text { forms (\%) }\end{array}$ & $r: 0.03$ & -0.008 to 0.07 & 0.12 & $0.8 \pm 1.4$ & $0.7 \pm 1.0$ & $0.9 \pm 1.4$ & $1.0 \pm 1.8$ & 0.77 \\
\hline $\begin{array}{l}\text { Leukocytes } \\
\left(\times 10^{6} / \mathrm{ml}\right)\end{array}$ & $r: 0.10$ & 0.03 to 0.11 & 0.0001 & $0.4 \pm 0.9$ & $0.3 \pm 0.6^{a, b}$ & $0.4 \pm 0.9^{a}$ & $0.5 \pm 1.2^{b}$ & $\begin{array}{l}\text { a } 0.002, \\
\text { b0.0002 }\end{array}$ \\
\hline Vitality (\%) & $r:-0.10$ & -0.13 to -0.05 & 0.006 & $64.5 \pm 14.9$ & $66.9 \pm 14.0^{\mathrm{a}, \mathrm{b}}$ & $65.0 \pm 15.0^{a, c}$ & $61.3 \pm 14.8^{b, c}$ & $\begin{aligned} & { }^{\mathrm{a}} 0.03 \\
\mathrm{~b}, \mathrm{c} & <0.0001\end{aligned}$ \\
\hline
\end{tabular}

Values within rows with the same superscript letter were significantly different.

Table 3. Correlation between sperm DNA fragmentation, sperm chromatin packing, sperm apoptosis and sperm mitochondrial membrane potential according to the sexual abstinence period.

\begin{tabular}{|c|c|c|c|c|c|c|c|c|}
\hline \multirow[b]{2}{*}{$\begin{array}{l}\text { Semen } \\
\text { Parameters }\end{array}$} & \multicolumn{3}{|c|}{ Regression analysis } & \multicolumn{5}{|c|}{ Sexual Abstinence Period Groups } \\
\hline & $\begin{array}{c}\text { Spearman's } \\
\text { rank } \\
\text { correlation }\end{array}$ & $\begin{array}{l}\text { 95\% Confidence } \\
\text { Interval }\end{array}$ & $\boldsymbol{p}$ & $\begin{array}{c}\text { Total } \\
\mathrm{n}: \mathbf{2 4 5 8}\end{array}$ & $\begin{array}{l}<2 \text { days } \\
\mathrm{n}: 244\end{array}$ & $\begin{array}{l}2-5 \text { days } \\
n: 1932\end{array}$ & $\begin{array}{c}>5 \text { days } \\
\mathrm{n}: 282\end{array}$ & $p$ \\
\hline $\begin{array}{l}\text { DNA } \\
\text { fragmentation } \\
(\%)\end{array}$ & $r: 0.12$ & 0.16 to 0.44 & $<0.0001$ & $15.4 \pm 8.5$ & $14.5 \pm 8.2^{\mathrm{a}}$ & $15.3 \pm 8.4^{b}$ & $17.1 \pm 9.0^{\mathrm{a}, \mathrm{b}}$ & $\begin{array}{l}{ }^{\mathrm{a}} 0.001 \\
{ }^{\mathrm{b}} 0.002\end{array}$ \\
\hline $\begin{array}{l}\text { Abnormal MMP } \\
(\%)\end{array}$ & $r: 0.10$ & 0.03 to 0.16 & 0.003 & $25.7 \pm 16.4$ & $23.3 \pm 14.0^{a}$ & $25.6 \pm 16.5$ & $28.6 \pm 17.5^{\mathrm{a}}$ & ${ }^{\mathrm{a}} 0.01$ \\
\hline $\begin{array}{l}\mathrm{CMA}_{3} \text { positivity } \\
(\%)\end{array}$ & $\mathrm{r}:-0.12$ & -0.14 to -0.04 & $<0.0001$ & $56.1 \pm 15.2$ & $59.8 \pm 15.3^{a, b}$ & $56.1 \pm 15.2^{\mathrm{a}, \mathrm{c}}$ & $53.2 \pm 14.2^{\mathrm{b}, \mathrm{c}}$ & $\begin{array}{c}{ }^{\mathrm{a}} 0.005 \\
{ }^{\mathrm{b}} 0.0002 \\
{ }^{\mathrm{c}} 0.02\end{array}$ \\
\hline Apoptosis (\%) & $r: 0.01$ & -0.03 to 0.06 & 0.21 & $19.2 \pm 7.9$ & $19.3 \pm 8.5$ & $19.1 \pm 7.9$ & $20.2 \pm 7.3$ & 0.17 \\
\hline
\end{tabular}

Values within rows with the same superscript letter were significantly different.

et al., 1992; Tur-Kaspa et al., 1994) that noted that lower abstinence time improves the percentage of sperm motility, and particularly the total motile sperm counts among patients with male factor infertility. Therefore, pooling sequential ejaculates was recommended to increase success rates (Tur-Kaspa et al., 1994). One of the reasons for the relatively fast reduction in this parameter can be related to the increased production of ROS. Oxidative stress is a condition associated with an increased rate of cellular damage induced by oxygen and oxygen-derived oxidants, known as reactive oxygen species (Sikka et al., 1995). Damaged spermatozoa (Iwasaki et al., 1992) or infiltrating leukocytes (Kessopoulu et al., 1994) are source of ROS, which is correlated with decreased sperm motility. In fact, higher levels of ROS have been found in semen of infertile men, when compared with the semen from fertile patients (Levitas et al., 2005; Iwasaki et al., 1992, Aitken et al., 1991).
To summarize, our results show that semen variables such as semen volume and total sperm count, increase with semen abstinence period. Conversely, the longer the SAP, the greater the semen volume, sperm concentration, leucocyte concentration, DNA fragmentation and abnormal mitochondrial membrane potential.

Further, the sperm concentration in larger abstinence periods was substantially higher, and this can be ascribed to the fact that reserves were available and stored in the epididymis. Due to the lower abstinence period, the reserves were depleted and total sperm count decreased with shorter abstinence periods (Rao et al., 2015). In our study, the sperm concentration was significantly increased after both 2-5 and $>5$ days' abstinence in comparison with a 2 day-abstinence. These findings raise a question concerning daily sperm production. We have found that 2-5 and $>5$ days abstinence produced the greatest semen volumes and sperm concentrations in comparison with 2 day's abstinence. 
Similarly to its influence on sperm motility, an increase in semen oxidative stress related to the sperm DNA fragmentation index was found in patients with male factor infertility, compared with cases of fertile donors (Levitas et al., 2005; Saleh et al., 2003). Some researchers have reported a relationship between oxidative stress and male infertility, and suggest that treatments for infertility in these men should include strategies to reduce oxidative stress (Pasqualotto et al., 2000).

DNA integrity of spermatozoa has been considered an important parameter in fertility studies (Mayorga-Torres et al., 2013; Evenson 2013; Evenson et al., 1999; Gil-Villa et al., 2009; 2010; Rodríguez et al., 2011). Evenson et al. found that semen samples with a DNA fragmentation index of more than $29 \%$ has an increased likelihood of reduced fertility (Mayorga-Torres et al., 2015; Evenson et al., 1999).

The results from the present study showed that the DNA fragmentation percentage increased in the longer periods of abstinence. Similar studies have shown that shorter abstinence periods lead to a greater reduction in the incidence of sperm DNA fragmentation and an increase on pregnancy rates after assisted reproductive techniques (Sánchez-Martín et al., 2013; Gosálvez et al., 2011). Variations in the results reported in the literature may be related to the technique used and/or the population analyzed.

The quality of sperm chromatin packaging has been reported to play an important role during fertilization and early embryo development. Several investigators have used chromomycin A3 to evaluate sperm chromatin packaging in relationship to IVF outcome, similar to the present study. Chromomycin A3 values have been reported to be inversely correlated with sperm count and in vitro fertilization (Lolis et al., 1996; Iranpour et al., 2000). In contrast to DNA fragmentation data, there appeared to be a negative influence of a short abstinence interval (24 hours) on sperm chromatin packaging. We found that the percentage of sperm with immature chromatin was significantly higher after 2 days' abstinence in comparison with after 2-5 days' abstinence and $>5$ days abstinence. Sperm nuclear condensation serves, in part, as a protection mechanism for the DNA. Poorly condensed chromatin is more vulnerable to the potentially deleterious influences of environmental factors, such as peroxidation.

In our study, the abnormal MMP was signicantly higher in patients who maintained a longer period of abstinence than those who maintained a shorter abstinence period. It has been well described in studies of ROS production and sperm physiology that these highly reactive chemical species play a major role in many sperm processes such as maturation, motility and capacitation (Kothari et al., 2010). Nevertheless, ROS levels must be controlled within physiological boundaries as overproduction or lack of sufficient antioxidant systems can lead to the development of oxidative stress, and it may affect mitochondrial function.

In conclusion, increase in the sexual abstinence period influences sperm quality. This study reinforces the importance of the duration of ejaculatory abstinence on semen parameter variation. It highlights the deleterious effect of increased abstinence on DNA damage, which is most likely associated with ROS (mitochondrial damage/number of leukocytes). The increase in chromatin packaging can represent a protective feature for DNA. However, pitfalls of the chromomycin A3 method cannot be excluded.

\section{CONFLICT OF INTERESTS}

No conflict of interest has been declared.

\section{Corresponding author:}

Jose G Franco Jr.

Center for Human Reproduction Prof Franco Jr.

Ribeirão Preto - SP - Brazil.

E-mail: crh@crh.com.br

\section{REFERENCES}

Agarwal A, Said TM. Role of sperm chromatin abnormalities and DNA damage in male infertility. Hum Reprod Update. 2003;9:331-45. PMID: 12926527 DOI: 10.1093/humupd/dmg027

Agarwal A, Gupta S, Du Plessis S, Sharma R, Esteves SC, Cirenza C, Eliwa J, Al-Najjar W, Kumaresan D, Haroun N, Philby S, Sabanegh E. Abstinence Time and Its Impact on Basic and Advanced Semen Parameters. Urology. 2016;94:102-10. PMID: 27196032 DOI: 10.1016/j.urology.2016.03.059

Aitken RJ, Irvine DS, Wu FC. Prospective analysis of sperm-oocyte fusion and reactive oxygen species generation as a criteria for the diagnosis of infertility. Am J Obstet Gynecol. 1991;164:542-51. PMID: 1992700 DOI: 10.1016/S0002-9378(11)80017-7

Alvarez C, Castilla JA, Martínez L, Ramírez JP, Vergara F, Gaforio Jj. Biological variation of seminal parameters in healthy subjects. Hum Reprod. 2003;18:2082-8. PMID: 14507825 DOI: $10.1093 /$ humrep/deg430

Amann RP, Chapman PL. Total sperm per ejaculate of men: obtaining a meaningful value or a mean value with appropriate precision. J Androl. 2009;30:642-9. PMID: 19443908 DOI: $10.2164 /$ jandrol.108.006825

Auger J, Eustache F, Ducot B, Blandin T, Daudin M, Diaz I, Matribi SE, Gony B, Keskes L, Kolbezen M, Lamarte A, Lornage J, Nomal N, Pitaval G, Simon O, Virant-Klun I, Spira A, Jouannet P. Intra- and inter-individual variability in human sperm concentration, motility and vitality assessment during a workshop involving ten laboratories. Hum Reprod. 2000;15:2360-8. PMID: 11056133 DOI: 10.1093 /humrep/15.11.2360

Blackwell JM, Zaneveld LJ. Effect of abstinence on sperm acrosin, hypoosmotic swelling, and other semen variables. Fertil Steril. 1992;58:798-802. PMID: 1426327 DOI: $10.1016 / \mathrm{S} 0015-0282(16) 55330-8$

Cardona Maya WD, Berdugo Gutiérrez JA, de los Ríos J, Cadavid Jaramillo AP. Functional evaluation of sperm in Colombianfertilemen. ArchEspUrol. 2007;60:827-31.PMID: 17937349 DOI: $10.4321 /$ S0004-06142007000700019

Castilla JA, Alvarez C, Aguilar J, González-Varea C, Gonzalvo MC, Martínez L. Influence of analytical and biological variation on the clinical interpretation of seminal parameters. Hum Reprod. 2006;21:847-51. PMID: 16361288 DOI: $10.1093 /$ humrep/dei423

De Jonge C, LaFromboise M, Bosmans E, Ombelet W, Cox A, Nijs M. Influence of the abstinence period on human sperm quality. Fertil Steril. 2004;82:57-65. PMID: 15236990 DOI: $10.1016 /$ j.fertnstert.2004.03.014 
Du Plessis SS, McAllister DA, Luu A, Savia J, Agarwal A, Lampiao $F$. Effects of $\mathrm{H}_{2} \mathrm{O}_{2}$ exposure on human sperm motility parameters, reactive oxygen species levels and nitric oxide levels. Andrologia. 2010;42:206-10. PMID: 20500750 DOI: 10.1111/j.1439-0272.2009.00980.x

Evenson DP, Jost LK, Marshall D, Zinaman MJ, Clegg E, Purvis $\mathrm{K}$, de Angelis $\mathrm{P}$, Claussen OP. Utility of the sperm chromatin structure assay as a diagnostic and prognostic tool in the human fertility clinic. Hum Reprod. 1999;14:1039-49. PMID: 10221239 DOI: 10.1093/humrep/14.4.1039

Evenson DP. Sperm chromatin structure assay (SCSA(R)). Methods Mol Biol. 2013;927:147-64. PMID: 22992911 DOI: $10.1007 / 978-1-62703-038-0 \_14$

Franco JG Jr, Mauri AL, Petersen CG, Massaro FC, Silva LF, Felipe V, Cavagna M, Pontes A, Baruffi RL, Oliveira JB, Vagnini LD. Large nuclear vacuoles are indicative of abnormal chromatin packaging in human spermatozoa. Int J Androl. 2012;35:46-51. PMID: 21535011 DOI: 10.1111/j.1365-2605.2011.01154.x

Gil-Villa AM, Cardona-Maya W, Agarwal A, Sharma R, Cadavid A. Role of male factor in early recurrent embryo loss: do antioxidants have any effect? Fertil Steril. 2009;92:565-71. PMID: 18829003 DOI: 10.1016/j.fertnstert.2008.07.1715

Gil-Villa AM, Cardona-Maya W, Agarwal A, Sharma R, Cadavid A. Assessment of sperm factors possibly involved in early recurrent pregnancy loss. Fertil Steril. 2010;94:1465-72. PMID: 19540481 DOI: 10.1016/j.fertnstert.2009.05.042

Gosálvez J, González-Martínez M, López-Fernández C, Fernández JL, Sánchez-Martín P. Shorter abstinence decreases sperm deoxyribonucleic acid fragmentation in ejaculate. Fertil Steril. 2011;96:1083-6. PMID: 21924714 DOI: $10.1016 /$ j.fertnstert.2011.08.027

Hornstein MD, Cohen JN, Thomas PP, Gleason RE, Friedman $A J$, Mutter GL. The effect of consecutive day inseminations on semen characteristics in an intrauterine insemination program. Fertil Steril. 1992;58:433-5. PMID: 1633917 DOI: $10.1016 / S 0015-0282(16) 55207-8$

Iranpour FG, Nasr-Esfahani MH, Valojerdi MR, al-Taraihi TM. Chromomycin A3 staining as a useful tool for evaluation of male fertility. J Assist Reprod Genet. 2000;17:60-6. PMID: 10754785 DOI: $10.1023 / A: 1009406231811$

Iwasaki A, Gagnon C. Formation of reactive oxygen species in spermatozoa of infertile patients. Fertil Steril. 1992;57:409-16. PMID: 1735495 DOI: $10.1016 /$ S0015-0282(16)54855-9

Jouannet P, Czyglik F, David G, Mayaux MJ, Spira A, Moscato ML, Schwartz D. Study of a group of 484 fertile men. Part I: distribution of semen characteristics. Int J Androl. 1981;4:440-9. PMID: 7298227 DOI: $10.1111 /$ j.1365-2605.1981.tb00728.x

Kessopoulou E, Tomlinson MJ, Barratt CL, Bolton AE, Cooke ID. Origin of reactive oxygen species in human semen: spermatozoa or leucocytes? J Reprod Fertil. 1994;94:46370. PMID: 1593545 DOI: 10.1530/jrf.0.0940463
Kothari S, Thompson A, Agarwal A, du Plessis SS. Free radicals: their beneficial and detrimental effects on sperm function. Indian J Exp Biol. 2010;48:425-35. PMID: 20795359

Le Lannou D, Colleu D, Boujard D, Le Couteux A, Lescoat $D$, Segalen J. Effect of duration of abstinence on maturity of human spermatozoa nucleus. Arch Androl. 1986;17:358. PMID: 3789875 DOI: 10.3109/01485018608986954

Lehavi O, Botchan A, Paz G, Yogev L, Kleiman SE, Yavetz $H$, Hauser R. Twenty-four hours abstinence and the quality of sperm parameters. Andrologia. 2014;46:692-7. PMID: 23879893 DOI: $10.1111 /$ and.12137

Levitas E, Lunenfeld E, Weiss N, Friger M, Har-Vardi I, Koifman A, Potashnik G. Relationship between the duration of sexual abstinence and semen quality: analysis of 9,489 semen samples. Fertil Steril. 2005;83:1680-6. PMID: 15950636 DOI: $10.1016 /$ j.fertnstert.2004.12.045

Lolis D, Georgiou I, Syrrou M, Zikopoulos K, Konstantelli M, Messinis I. Chromomycin A3-staining as an indicator of protamine deficiency and fertilization. Int J Androl. 1996;19:23-7. PMID: 8698534 DOI: 10.1111/j.1365-2605.1996.tb00429.x

Makkar G, Ng EH, Yeung WS, Ho PC. A comparative study of raw and prepared semen samples from two consecutive days. J Reprod Med. 2001;46:565-72. PMID: 11441681

Matilsky M, Battino S, Ben-Ami M, Geslevich Y, Eyali $V$, Shalev E. The effect of ejaculatory frequency on semen characteristics of normozoospermic and oligozoospermic men from an infertile population. Hum Reprod. 1993;8:71-3. PMID: 8458930 DOI: 10.1093/oxfordjournals. humrep.a137877

Mayorga-Torres BJ, Cardona-Maya W, Cadavid A, Camargo M. Evaluation of sperm functional parameters in normozoospermic infertile individuals. Actas Urol Esp. 2013;37:221-7. PMID: 23246107 DOI: 10.1016/j.acuro.2012.06.008

Mayorga-Torres BJ, Camargo M, Agarwal A, Plessis SS, Cavidad AP, Maya WD. Influence of ejaculation frequency on seminal parameters. Reprod Biol Endocrinol. 2015;13:47. PMID: 25994017 DOI: 10.1186/s12958-015-0045-9

Mayorga-Torres JM, Agarwal A, Roychoudhury S, Cadavid A, Cardona-Maya WD. Can a short term of repeated ejaculations affect seminal parameters? J Reprod Infertil. 2016;17:177-83. PMID: 27478772

Mortimer D, Templeton AA, Lenton EA, Coleman RA. Influence of abstinence and ejaculation-to-analysis delay on semen analysis parameters of suspected infertile men. Arch Androl. 1982;8:251-6. PMID: 7114956 DOI: $10.3109 / 01485018208990205$

Oliveira JBA, Petersen CG, Mauri AL, Vagnani LD, Baruffi RLR, Franco JG. The effects of age on sperm quality: an evaluation of 1,500 semen samples. JBRA Assist Reprod. 2014;18:34-41. DOI: 10.5935/1518-0557.20140002 
Padova G, Tita P, Briguglia G, Giuffrida D. Influence of abstinence length on ejaculate characteristics. Acta Eur Fertil. 1988;19:29-31. PMID: 3414329

Pasqualotto FF, Sharma RK, Nelson DR, Thomas AJ Jr, Agarwal A. Relationship between oxidative stress, semen characteristics, and clinical diagnosis in men undergoing infertility investigation. Fertil Steril. 2000;73:459-64. PMID: 10688996 DOI: 10.1016/S0015-0282(99)00567-1

Rao M, Meng TQ, Hu SH, Guan HT, Wei QY, Xia W, Zhu $\mathrm{CH}$, Xiong CL. Evaluation of semen quality in 1808 university students, from Wuhan, Central China. Asian J Androl. 2015;17:111-6. PMID: 25337834 DOI: $10.4103 / 1008-682 X .135984$

Rodríguez E, Gil-Villa AM, Aguirre-Acevedo DC, CardonaMaya W, Cadavid AP. Evaluation of atypical semen parameters in individuals whose couples had a history of early recurrent embryo death: in search for a reference value. Biomedica. 2011;31:100-7. PMID: 22159488 DOI: $10.1590 /$ S0120-41572011000100012

Saleh RA, Agarwal A, Nada EA, El-Tonsy MH, Sharma RK, Meyer A, Nelson DR, Thomas AJ. Negative effects of increased sperm DNA damage in relation to seminal oxidative stress in men with idiopathic and male factor infertility. Fertil Steril. 2003;79:1597-605. PMID: 12801566 DOI: $10.1016 /$ S0015-0282(03)00337-6

Sánchez-Martín P, Sánchez-Martín F, González-Martínez M, Gosálvez J. Increased pregnancy after reduced male abstinence. Syst Biol Reprod Med. 2013;59:256-60. PMID: 23651301 DOI: 10.3109/19396368.2013.790919

Sauer MV, Zeffer KB, Buster JE, Sokol RZ. Effect of abstinence on sperm motility in normal men. Am J Obstet Gynecol. 1988;158:604-7. PMID: 3348323 DOI: $10.1016 / 0002-9378(88) 90038-5$
Schwartz D, Laplanche A, Jouannet P, David G. Withinsubject variability of human semen in regard to sperm count, volume, total number of spermatozoa and length of abstinence. J Reprod Fertil. 1979;57:391-5. PMID: 513028 DOI: $10.1530 /$ jrf.0.0570391

Sikka SC, Rajasekaran M, Hellstrom WJ. Role of oxidative stress and antioxidants in male infertility. J Androl. 1995;16:464-8. PMID: 8867595 DOI: $10.1002 / j .1939-4640.1995 . t b 00566 . x$

Silva LF, Oliveira JB, Petersen CG, Mauri AL, Massaro FC, Cavagna M, Baruffi RL, Franco JG Jr. The effects of male age on sperm analysis by motile sperm organelle morphology examination (MSOME). Reprod Biol Endocrinol. 2012;10:19. PMID: 22429861 DOI: $10.1186 / 1477-7827-10-19$

Sullivan R, Mieusset R. The human epididymis: its function in sperm maturation. Hum Reprod Update. 2016;22:57487. PMID: 27307387 DOI: 10.1093/humupd/dmw015

Tur-Kaspa I, Maor Y, Levran D, Yonish M, Mashiach S, Dor J. How often should infertile men have intercourse to achieve conception? Fertil Steril. 1994;62:370-5. PMID: 8034087 DOI: $10.1016 /$ S0015-0282(16)56893-9

Vagnini L, Baruffi RL, Mauri AL, Petersen CG, Massaro FC, Pontes A, Oliveira JB, Franco JG Jr. The effects of male age on sperm DNA damage in an infertile population. Reprod Biomed Online. 2007;15:514-9. PMID: 18028741 DOI: $10.1016 / \mathrm{S} 1472-6483(10) 60382-3$

WHO - World Health organization. WHO laboratory manual for the examination and processing of human semen. 5th ed. Geneva: WHO Press; 2010. 